\title{
Article \\ A Rapid Self-Assembly Peptide Hydrogel for Recruitment and Activation of Immune Cells
}

\author{
Ruyue Luo ${ }^{\dagger}$, Yuan Wan ${ }^{\dagger}$, Xinyi Luo, Guicen Liu, Zhaoxu Li ${ }^{D}$, Jialei Chen, Di Su, Na Lu and Zhongli Luo *D
}

check for updates

Citation: Luo, R.; Wan, Y.; Luo, X.; Liu, G.; Li, Z.; Chen, J.; Su, D.; Lu, N.; Luo, Z. A Rapid Self-Assembly Peptide Hydrogel for Recruitment and Activation of Immune Cells. Molecules 2022, 27, 419. https:// doi.org/10.3390/molecules27020419

Academic Editor: Mustafa O. Guler

Received: 6 December 2021

Accepted: 4 January 2022

Published: 10 January 2022

Publisher's Note: MDPI stays neutral with regard to jurisdictional claims in published maps and institutional affiliations.

Copyright: (C) 2022 by the authors. Licensee MDPI, Basel, Switzerland. This article is an open access article distributed under the terms and conditions of the Creative Commons Attribution (CC BY) license (https:// creativecommons.org/licenses/by/ $4.0 /)$.

\author{
Molecular Medicine and Cancer Research Center, College of Basic Medical Sciences, Chongqing Medical \\ University, Chongqing 400016, China; ruyueluo@163.com (R.L.); wanyuan@stu.cqmu.edu.cn (Y.W.); \\ xyl@stu.cqmu.edu.cn (X.L.); Liuguicen7@163.com (G.L.); lzxzsa@stu.cqmu.edu.cn (Z.L.); cj10917@sohu.com (J.C.); \\ sd199877@163.com (D.S.); Lunar@stu.cqmu.edu.cn (N.L.) \\ * Correspondence: Zhongliluo@163.com \\ † These authors contributed equally to this work.
}

\begin{abstract}
Self-assembly peptide nanotechnology has attracted much attention due to its regular and orderly structure and diverse functions. Most of the existing self-assembly peptides can form aggregates with specific structures only under specific conditions and their assembly time is relatively long. They have good biocompatibility but no immunogenicity. To optimize it, a self-assembly peptide named DRF3 was designed. It contains a hydrophilic and hydrophobic surface, using two N-terminal arginines, leucine, and two c-terminal aspartate and glutamic acid. Meanwhile, the c-terminal of the peptide was amidated, so that peptide segments were interconnected to increase diversity. Its characterization, biocompatibility, controlled release effect on antigen, immune cell recruitment ability, and antitumor properties were examined here. Congo red/aniline blue staining revealed that peptide hydrogel DRF3 could be immediately gelled in PBS. The stable $\beta$-sheet secondary structure of DRF3 was confirmed by circular dichroism spectrum and IR spectra. The observation results of cryo-scanning electron microscopy, transmission electron microscopy, and atomic force microscopy demonstrated that DRF3 formed nanotubule-like and vesicular structures in PBS, and these structures interlaced with each other to form ordered three-dimensional nanofiber structures. Meanwhile, DRF3 showed excellent biocompatibility, could sustainably and slowly release antigens, recruit dendritic cells and promote the maturation of dendritic cells (DCs) in vitro. In addition, DRF3 has a strong inhibitory effect on clear renal cell carcinoma (786-0). These results provide a reliable basis for the application of peptide hydrogels in biomedical and preclinical trials.
\end{abstract}

Keywords: self-assembly peptide; hydrogel; nanofiber structures; controlled release

\section{Introduction}

Nanomaterials are materials with nanoscale (size range from $0.1 \mathrm{~nm}$ to $100 \mathrm{~nm}$ ) structural units, which have been widely studied in the medical field with the development of nanotechnology [1,2].

Hydrogel is a material with a three-dimensional network structure $[3,4]$, which has the characteristics of soft consistency, porosity, and high water content [5], has been widely concerned and studied in the medical field. According to the gelling mode, hydrogels can be divided into covalent hydrogels and physical hydrogels [6,7]. Its composition can be divided into a macro-molecule hydrogel and small molecule hydrogel [8,9].

Small molecule hydrogels are formed by the self-assembly of small molecules with molecular weight usually less than 2000 [10,11]. Molecular self-assembly is a common phenomenon in organisms, which can spontaneously assemble and form stable structures without being affected by external forces $[12,13]$. Biomimetic self-assembly technology of nanomaterials has become one of the main methods for the preparation of nanomaterials [14,15], which simulates the living life activities and enables nanomaterials to spontaneously form stable structures based on the interaction of non-covalent bonds. 
These self-assembly peptides are pure in composition [16], stable in performance [17], non-immunogenicity [18], non-toxic in degradation products and have good biocompatibility and has been demonstrated to be used in cell culture [19,20], drug delivery [21,22], regenerative medicine and immunotherapy [23]. At present, most peptide hydrogels are only studied as vaccine adjuvants in immunotherapy. The reason is that peptide hydrogels with good biocompatibility do not have immunogenicity, while peptide hydrogels with immunogenicity have toxic effects on cells.

Here, a self-assembling peptide, DRF3, is developed that can self-assemble into ordered nanofibers in PBS. This paper aims to prepare peptide hydrogels with good biocompatibility and antitumor properties through rational design of DRF3 molecule, natural amino acid composition, and the peptide sequence of DRF3.

\section{Materials and Methods}

\subsection{Materials}

T25/T75 breathable cell culture flask was purchased from LABSELECT (Hangzhou, China), $4 \%$ paraformaldehyde, red blood cell lysate, and $1 \times$ PBS buffer were purchased from Biosharp (Anhui, China), 1640 medium was purchased from Gibco (Shanghai, China), and Bovine serum albumin V BSA (Albumin Bovine serum) was purchased from BioFrox (Einhausen, Germany). Cytokines IL-4 and GM-CSF were purchased from PeproteDN, 6-well, 24-well, and 96-well cell culture plates, and 96-well enzyme plates were purchased from Nest (Jiangsu, China). Trypsin was purchased from Hyclone (Logan, UT, USA). Monoclonal antibodies used in this paper were purchased from Abcam Company (Cambridgeshire, UK).

\subsection{Synthesis of DRF3}

DRF3 was designed by this research group. The sequence of DRF3 is Ac-(Arg Leu Asp Ile Lys Val Glu Phe $)_{2}-\mathrm{CONH}_{2}$, which is a linear polypeptide synthesized from $\mathrm{C}$ terminal to $\mathrm{N}$ terminal by Chengdu CP Biochem Co., Ltd. (Chengdu, China). The molecular weight and purity of peptides were determined by mass spectrometry and HPLC.

Experimental conditions of HPLC: Mobile Phase: A: 0.1\% TFA in $\mathrm{H}_{2} \mathrm{O}, \mathrm{B}: 0.09 \%$ TFA in $\left(80 \% \mathrm{ACN}+20 \% \mathrm{H}_{2} \mathrm{O}\right)$; Flow: $1.0 \mathrm{~mL} / \mathrm{min} 30.0 \%-90.0 \% \mathrm{~B}$ buffer in $20 \mathrm{~min}, 90.0 \% \mathrm{~B}$ buffer in 5 min; Column: PLRP-S 8u 300A $4.6 \times 250 \mathrm{~mm}$ A1389\#50C.

Experimental conditions of MS: Interface: ESI; Equipment: GK11010007; Nebulizing Gas Flow: $1.5 \mathrm{~L} / \mathrm{min}$; Interface Bias: $+4.5 \mathrm{kV}$; CDL Temp: 250; Drying Gas Flow: $5 \mathrm{~L} / \mathrm{min}$; Block temp: $200 \mathrm{~T}$; Flow: $0.2 \mathrm{~mL} / \mathrm{min}$; B.conc: $50 \% \mathrm{H}_{2} \mathrm{O} / 50 \% \mathrm{MeOH}$.

\subsubsection{Hydrogel Preparation}

The peptide solution was prepared by dissolving $10 \mathrm{mg}$ DRF3 in $1 \mathrm{~mL}$ sterile water. Then, $1 \mathrm{~mL}$ PBS was added into $1 \mathrm{~mL}$ peptide solution and assembled into a hydrogel at $4{ }^{\circ} \mathrm{C}$.

\subsubsection{Gelling Effect}

At $0,12,24$, and $48 \mathrm{~h}$ after assembly, the hydrogel was stained with Congo red/ aniline blue.

\subsection{Characterization of DRF3}

To observe the secondary structure of DRF3, JASCO J-815 Spectrometer (JASCO J-815, Tokyo, Japan) was used for detection.

AFM (Brooke Multimode 8, Boston, MA, USA) was used to obtain the surface topography and structure information of DRF3.

The sub-microstructure and ultrastructure of DRF3 were analyzed using low power TEM of BC200725-36: JEM-1200EX (120 KV) and high-power TEM of BC210712-86: FEI Talos F200X (FEI Corporation, Hillsboro, OR, USA).

The three-dimensional structure of DRF3 in a near-physiological state was obtained by Cryo-SEM (Hitachi SU8010, Tokyo, Japan). 
The molecular structure of DRF3 was analyzed by FT-IR spectrometer (Nicolet iS10, Madison, WI, USA) and UV-3600 plus (Shimadzu, Kyodo, Japan).

\subsection{Controlled Release}

Respectively, $50 \mu \mathrm{L} 2.5 \mathrm{mg} / \mathrm{mL}, 5.0 \mathrm{mg} / \mathrm{mL}$ and $10 \mathrm{mg} / \mathrm{mL}$ DRF3 aqueous solutions were mixed with $5 \mathrm{mg} / \mathrm{mL}$ OVA to prepare a peptide-OVA mixed solution, and incubated at $37^{\circ} \mathrm{C}$ for $30 \mathrm{~min}$. Then, $100 \mathrm{uL}$ PBS was added and incubated at $37^{\circ} \mathrm{C}$. At hour 1,2 , $3,5,7,9,12,24,30,35,40$, the upper PBS was sucked out, its absorbance at $562 \mathrm{~nm}$ was measured, and $100 \mu \mathrm{L}$ PBS was added for further incubation.

\subsection{Biocompatibility Assay of DRF3}

\subsubsection{Cell Culture}

Dendritic cells (DCs) were extracted from the healthy SPF c57 mice and cultured in RPMI-1640 medium containing 10\% FBS, GM-CSF $(20 \mathrm{ng} / \mathrm{mL})$ and IL-4 $(10 \mathrm{ng} / \mathrm{mL})$ at $37{ }^{\circ} \mathrm{C}$ incubator with $5 \% \mathrm{CO}_{2}$.

\subsubsection{Cell Survival Rate}

PBS, LPS, OVA, DRF3, and DRF3-OVA were co-cultured with DC, respectively. PBS was negative control, LPS was a positive control. The effect of DRF3 on DC survival was analyzed by fluorescence-activated cell sorting (FACS).

\subsubsection{The Effect on DCs Recruitment}

OVA-FITC, DRF3-FITC, and DRF3-OVA-FITC were co-cultured with DC, respectively. The effect on DCs recruitment was observed by confocal laser scanning microscope (CLSM).

\subsubsection{The Effect on DCs Maturation}

After seven days of co-culture, a CD86 antibody was added. The effect of DRF3 on DCs maturation was observed by confocal laser scanning microscope (CLSM) and the CD86 percentage was determined by flow cytometry.

\subsection{Cytotoxicity Assay on 786-0 Cells}

\subsubsection{Cell Culture}

The 786-0 cell line originates from humans. The 786-0 cells were purchased from BNCC and cultured in RMPI- 1640 medium containing $10 \%$ FBS at $37^{\circ} \mathrm{C}$ incubators with $5 \% \mathrm{CO}_{2}$.

\subsubsection{CCK8 Protocol}

Cytotoxicity was analyzed by cell counting kit-8 (CCK8) protocol. The cell suspension was inoculated with $1 \times 10^{5}$ cells $/ \mathrm{mL}$ in a 96-well cell culture plate, $100 \mu \mathrm{L}$ per well, and incubated at $37^{\circ} \mathrm{C}$ for $24 \mathrm{~h}$. Then, $100 \mu \mathrm{L}$ DRF3 with a concentration of $0.1-1 \mathrm{mg} / \mathrm{mL}$ was added, respectively and cultured at $37^{\circ} \mathrm{C}$ for $24 \mathrm{~h} .10 \mu \mathrm{L}$ CCK 8 was added to each well after a full reaction and incubated at $37^{\circ} \mathrm{C}$ for $1 \mathrm{~h}$. The absorbance was measured at 450 $\mathrm{nm}$ with a microplate reader.

\subsubsection{Statistical Analysis}

The experimental results were replicated 3 times or more. The data were expressed by mean $\pm \mathrm{SEM}$, and two independent sample t-test were used to compare the experimental results between the two groups. When $p<0.05$, the difference in experimental results was statistically significant. 


\section{Results}

3.1. Peptide Hydrogel Morphology

3.1.1. Congo Red/Aniline Blue Staining Analysis

Congo red/aniline blue staining showed that peptide hydrogel showed an evacuation film structure through the microscope at $0 \mathrm{~h}$ of self-assembling; the loose film began to assemble into a relatively dense lamellar structure at $12 \mathrm{~h}$; the dense lamellar structure began to appear at $24 \mathrm{~h}$ and formed a dense thin film structure with stable structure and clear boundary at $48 \mathrm{~h}$ (Figure 1$)$.

A


$\mathrm{B}$
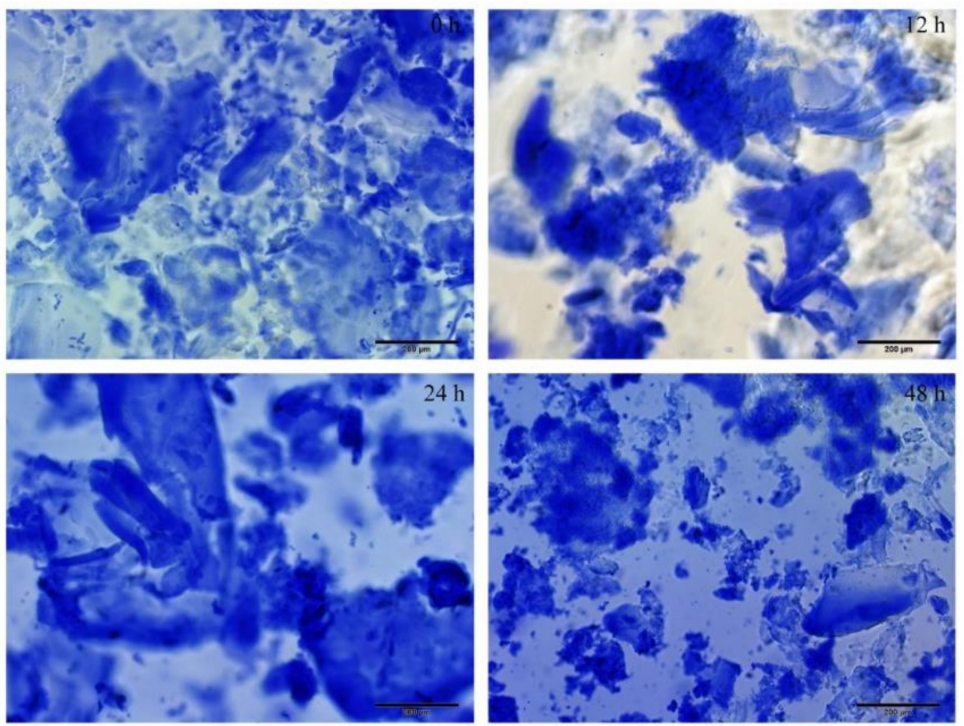

Figure 1. The results of the Congo red/aniline blue staining of peptide DRF3. (A) Congo red staining results of peptide DRF3 at $0 \mathrm{~h}, 12 \mathrm{~h}, 24 \mathrm{~h}$ and $48 \mathrm{~h}$; (B) aniline blue staining results of peptide DRF3 at $0 \mathrm{~h}, 12 \mathrm{~h}, 24 \mathrm{~h}$ and $48 \mathrm{~h}$.

\subsubsection{Mass Spectrometry Analysis}

The relative molecular masses of DRF3 were 2019.4 (Figure 2B).

\subsubsection{HPLC Analysis}

The purity of DRF3 was $82.3 \%$ (Figure $2 \mathrm{~A}$ ). 
A

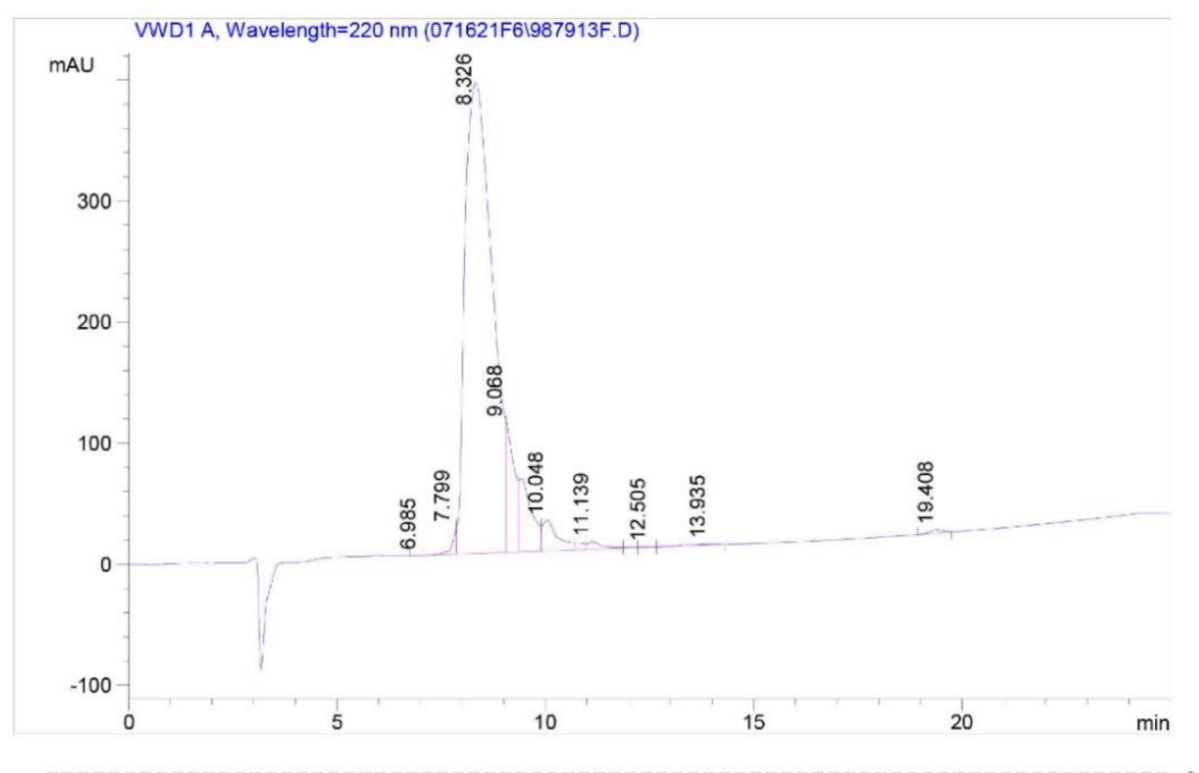

Signal 1:VWD1 A, Wavelength=220 nm

\begin{tabular}{|c|c|c|c|c|c|c|}
\hline $\begin{array}{l}\text { Peak } \\
\#\end{array}$ & $\begin{array}{l}\mathrm{RT} \\
{[\mathrm{min}]}\end{array}$ & Type & Height & $\begin{array}{c}\text { Width } \\
\text { [min] }\end{array}$ & Area & Area \% \\
\hline 1 & 6.985 & VP & 0.256 & 0.171 & 3.314 & 0.015 \\
\hline 2 & 7.727 & MF & 4.708 & 0.147 & 41.518 & 0.193 \\
\hline 3 & 7.799 & MF & 22.385 & 0.084 & 112.474 & 0.524 \\
\hline 4 & 8.326 & MF & 389.128 & 0.754 & 17603.611 & 82.035 \\
\hline 5 & 9.068 & FM & 107.457 & 0.213 & 1375.320 & 6.409 \\
\hline 6 & 9.425 & VV & 60.682 & 0.295 & 1294.297 & 6.032 \\
\hline 7 & 10.048 & VV & 25.336 & 0.358 & 656.936 & 3.061 \\
\hline 8 & 10.800 & VV & 5.764 & 0.224 & 87.457 & 0.408 \\
\hline 9 & 11.139 & UV & 6.165 & 0.348 & 153.025 & 0.713 \\
\hline 10 & 12.146 & ivV & 0.419 & 0.297 & 10.052 & 0.047 \\
\hline 11 & 12.505 & VP & 0.328 & 0.254 & 6.236 & 0.029 \\
\hline 12 & 13.935 & ivV & 0.889 & 0.734 & 52.813 & 0.246 \\
\hline 13 & 19.408 & BV & 2.713 & 0.358 & 61.618 & 0.287 \\
\hline
\end{tabular}

B

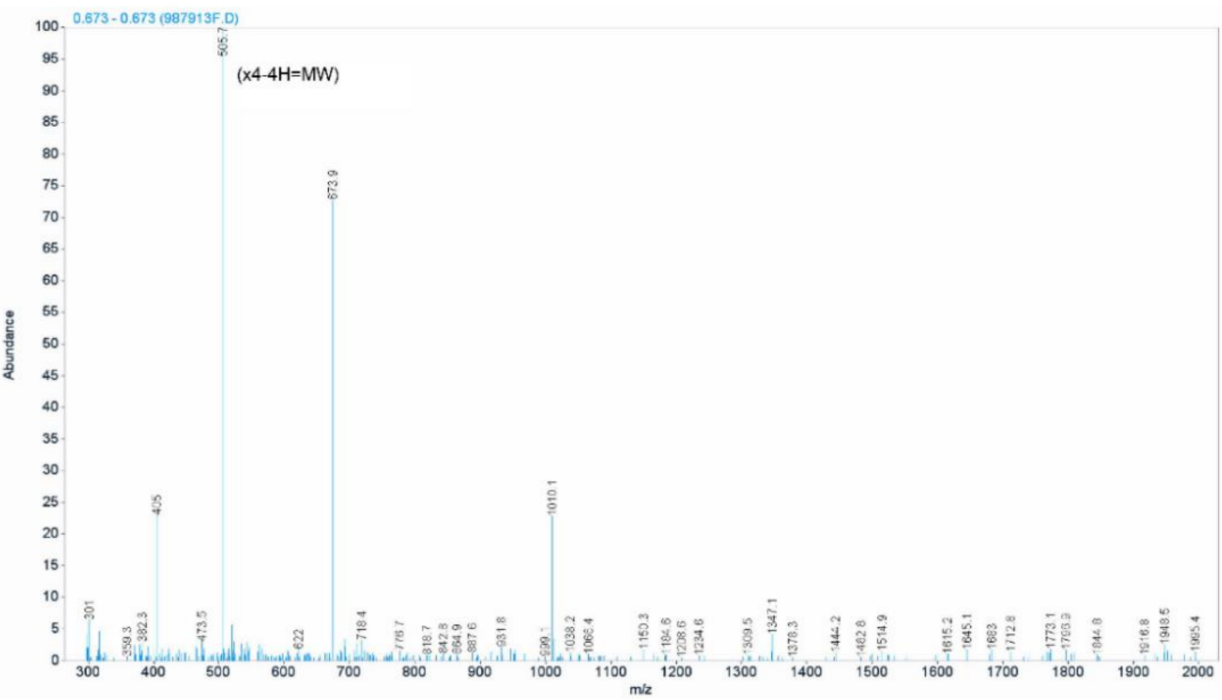

Figure 2. HPLC and Mass Spectrometry analysis of peptide DRF3. (A) HPLC analysis of peptide DRF3; (B) Mass Spectrometry analysis of peptide DRF3. 


\subsection{Secondary Structure of DRF3}

The circular dichroism spectrum showed DRF3 has a strong positive peak at $190 \mathrm{~nm}$ and a negative peak at $211 \mathrm{~nm}$ (Figure 3).

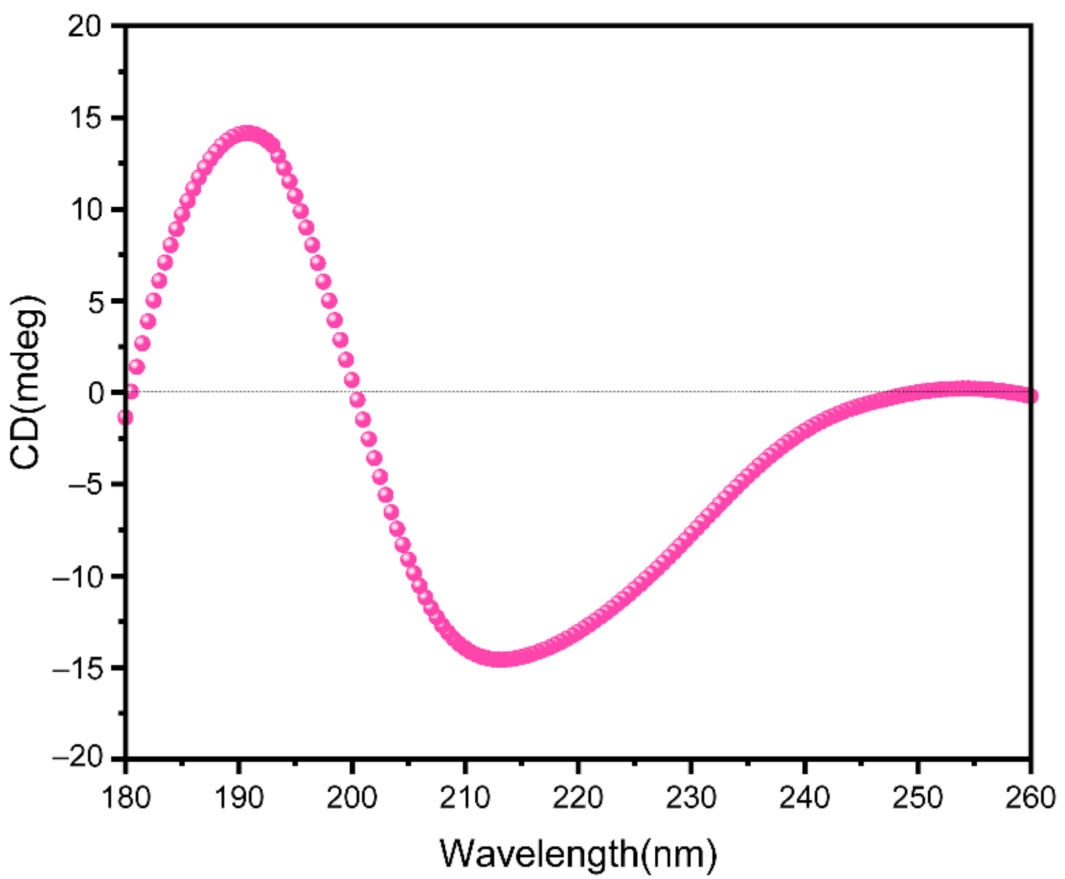

Figure 3. Circular dichroic analysis of DRF3.

DFR3' IR peaks reveal strong absorbance peaks in the $3400-2900 \mathrm{~cm}^{-1}, 1640-1600 \mathrm{~cm}^{-1}$, $1300-1100 \mathrm{~cm}^{-1}$, and $600-450 \mathrm{~cm}^{-1}$ areas. There are other faint peaks in the $3000-2900 \mathrm{~cm}^{-1}$, 2400-2000 cm $\mathrm{cm}^{-1}, 1661-1646 \mathrm{~cm}^{-1}, 1550-1450 \mathrm{~cm}^{-1}, 1400-1300 \mathrm{~cm}^{-1}, 1000-950 \mathrm{~cm}^{-1}$, 900-800 $\mathrm{cm}^{-1}$, and 750-650 $\mathrm{cm}^{-1}$ areas (Figure 4).

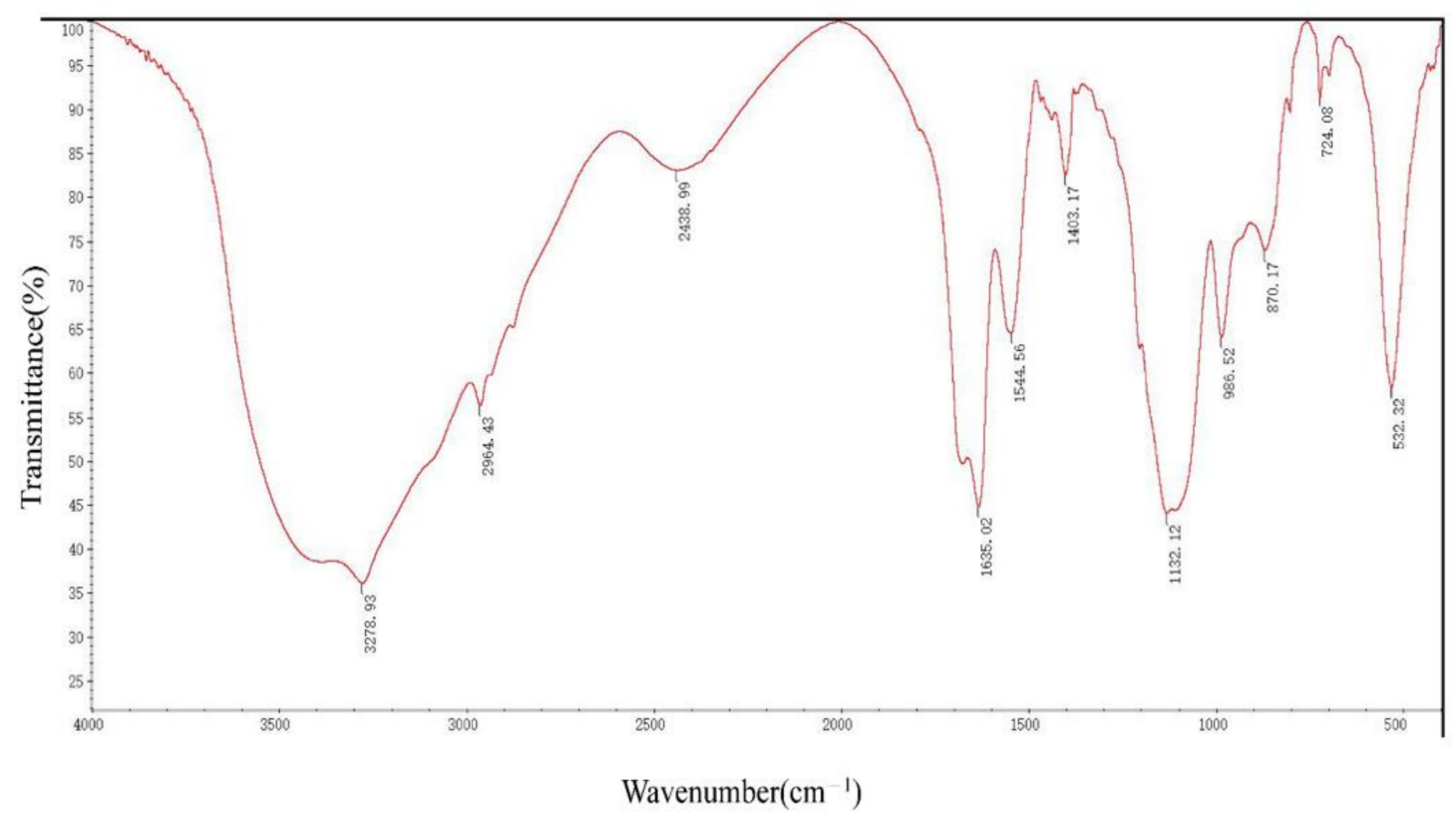

Figure 4. Infrared spectrogram analysis of DRF3. 


\subsection{Micro-Structural Measurements of DRF3}

\subsubsection{Cryo-SEM}

DRLF3 forms nanotubule-like and vesicle-like structures in PBS under electron microscopy, which interlaced with each other to form ordered three-dimensional nanofiber structures (Figure 5).
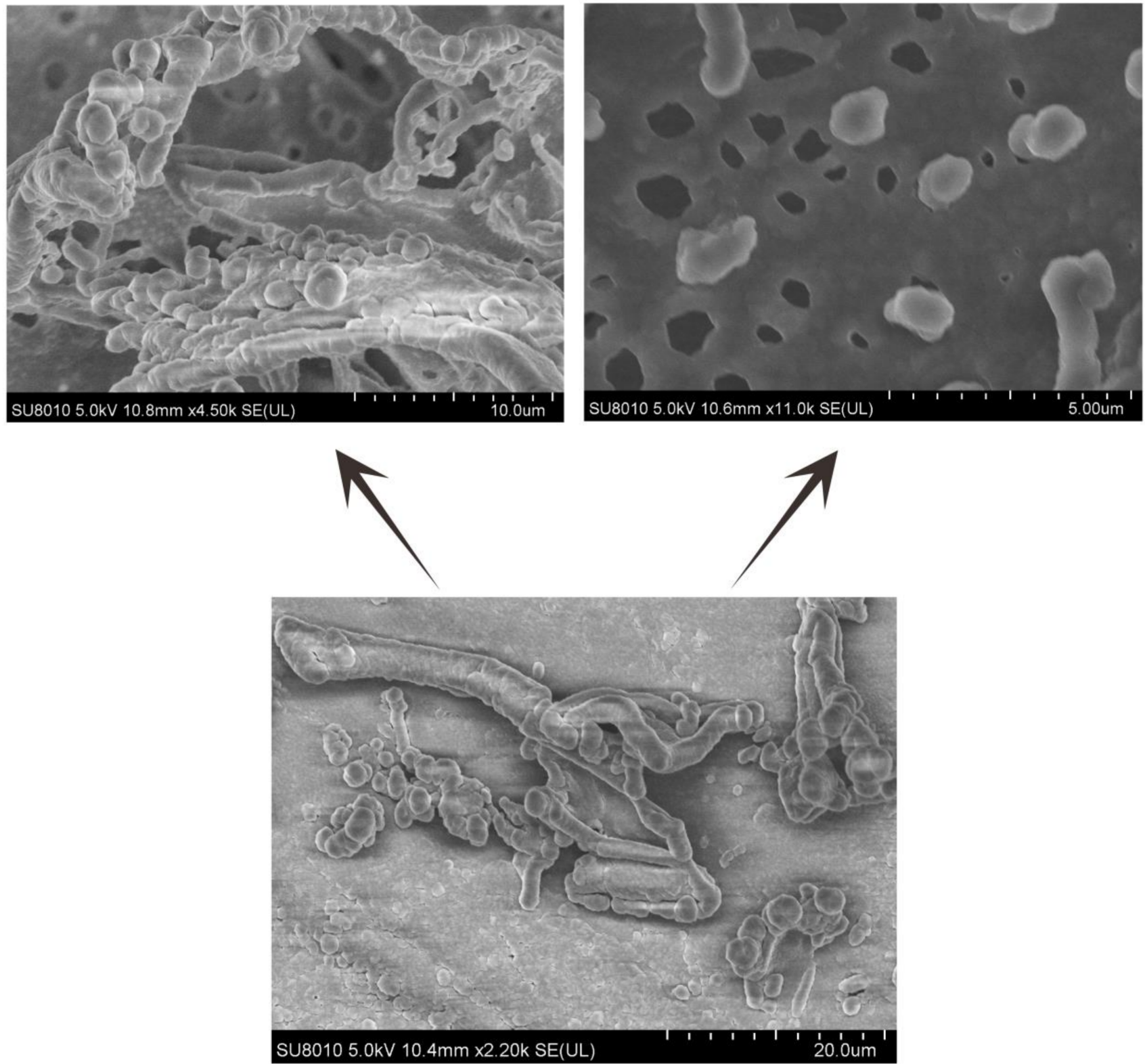

Figure 5. Cryogenic scanning electron microscopy (Cryo-SEM) analysis of DRF3.

\subsubsection{AFM}

AFM results reveal that DRF3 forms an ordered nanofiber structure after self-assembling. DRF3 nanofibers are about 11.6-19.2 nm in diameter (Figure 6). 

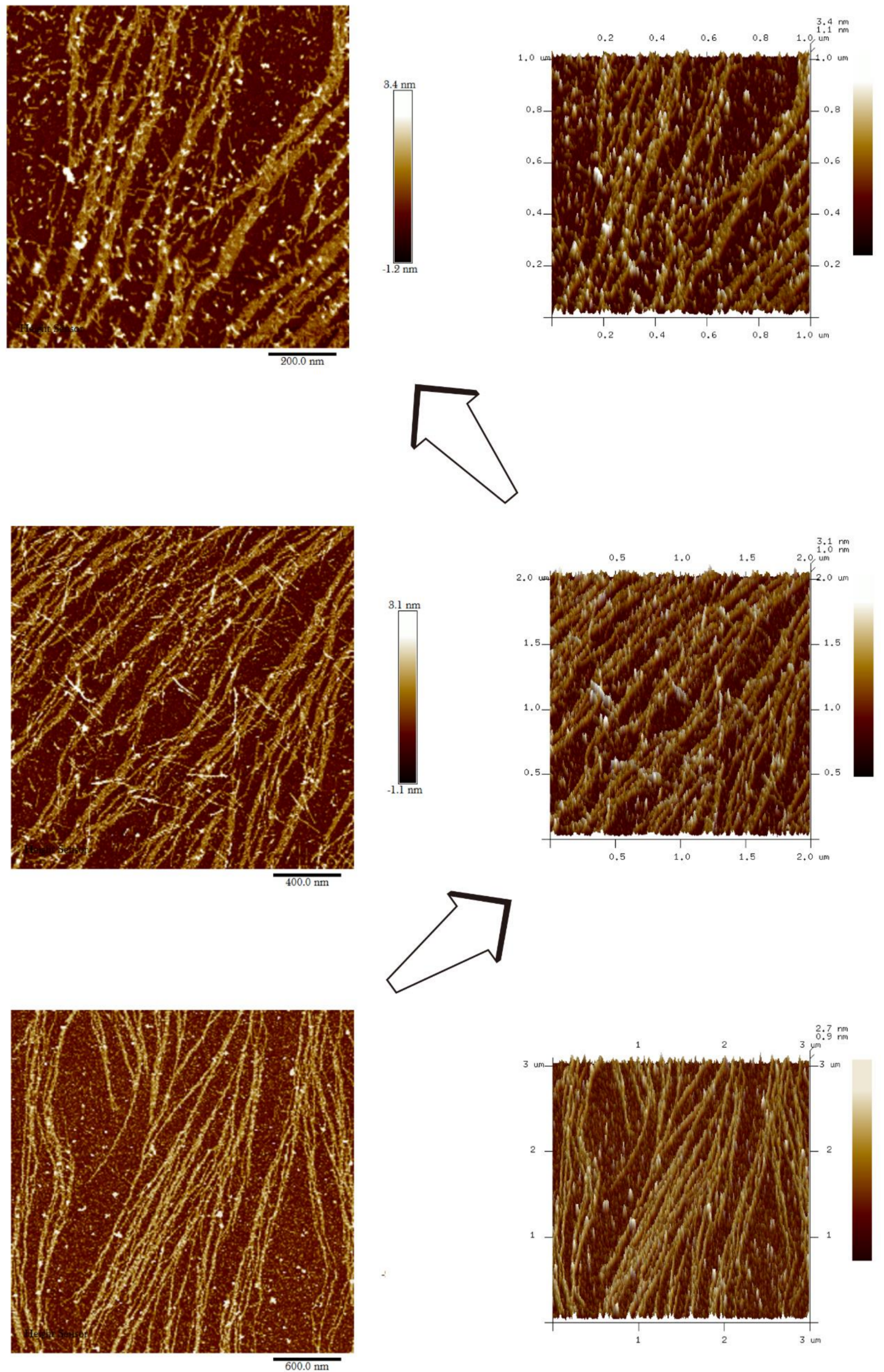

Figure 6. Atomic force microscopy analysis of DRF3. 


\subsubsection{TEM}

The results of TEM are consistent with those of AFM (Figure 7).


Figure 7. Transmission electron microscopy (TEM) analysis of DRF3. 


\subsubsection{DRF3-FITC}

Immunofluorescence images show that DRF3-FITC forms a dense network structure of nanofibers in PBS (Figure 8).

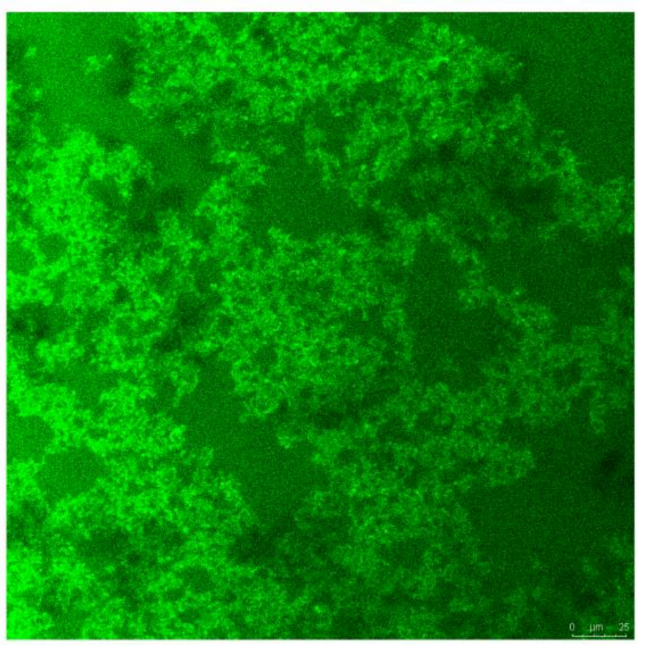

Figure 8. Immunofluorescence image of self-assembling peptide hydrogel DRF3-FITC in PBS.

\subsubsection{Controlled Release}

To test the controlled release effect of DRF3, we tested its controlled release effect on OVA. The results show that at the 12th $\mathrm{h}$, the three concentrations of DRF3 complete the controlled release of proteins. The controlled release rate of DRF3 to OVA reached $97 \%$ at $10 \mathrm{mg} / \mathrm{mL}, 82 \%$ at $5 \mathrm{mg} / \mathrm{mL}$ and $88.6 \%$ at $2.5 \mathrm{mg} / \mathrm{mL}$ (Figure 9).

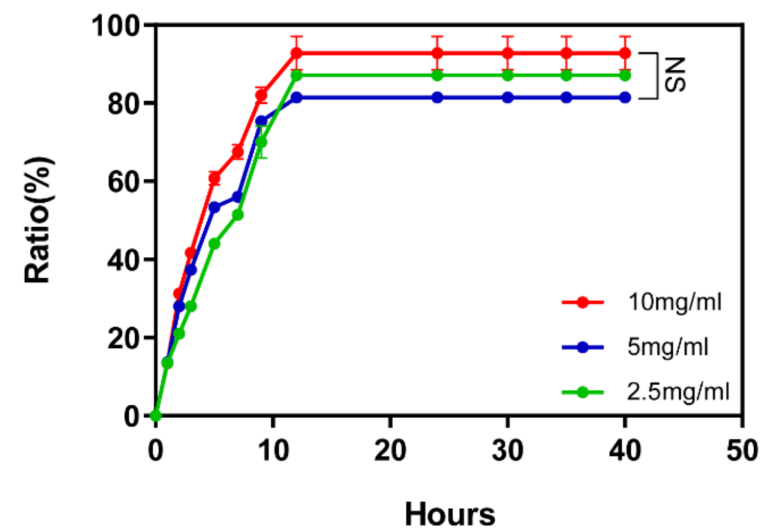

Figure 9. Controlled release of OVA in different concentrations of self-assembling peptide hydrogel DRF3 (The results were repeated three times, shown as mean \pm SEM; NS means no significant differences $p>0.05)$.

\subsection{Biocompatibility of DRF3}

3.4.1. Survival Rate of DCs

Confocal microscope observation showed that the DC in the PBS group showed higher apoptosis, while the DC in other groups showed no obvious apoptosis (Figure 10A). 
A
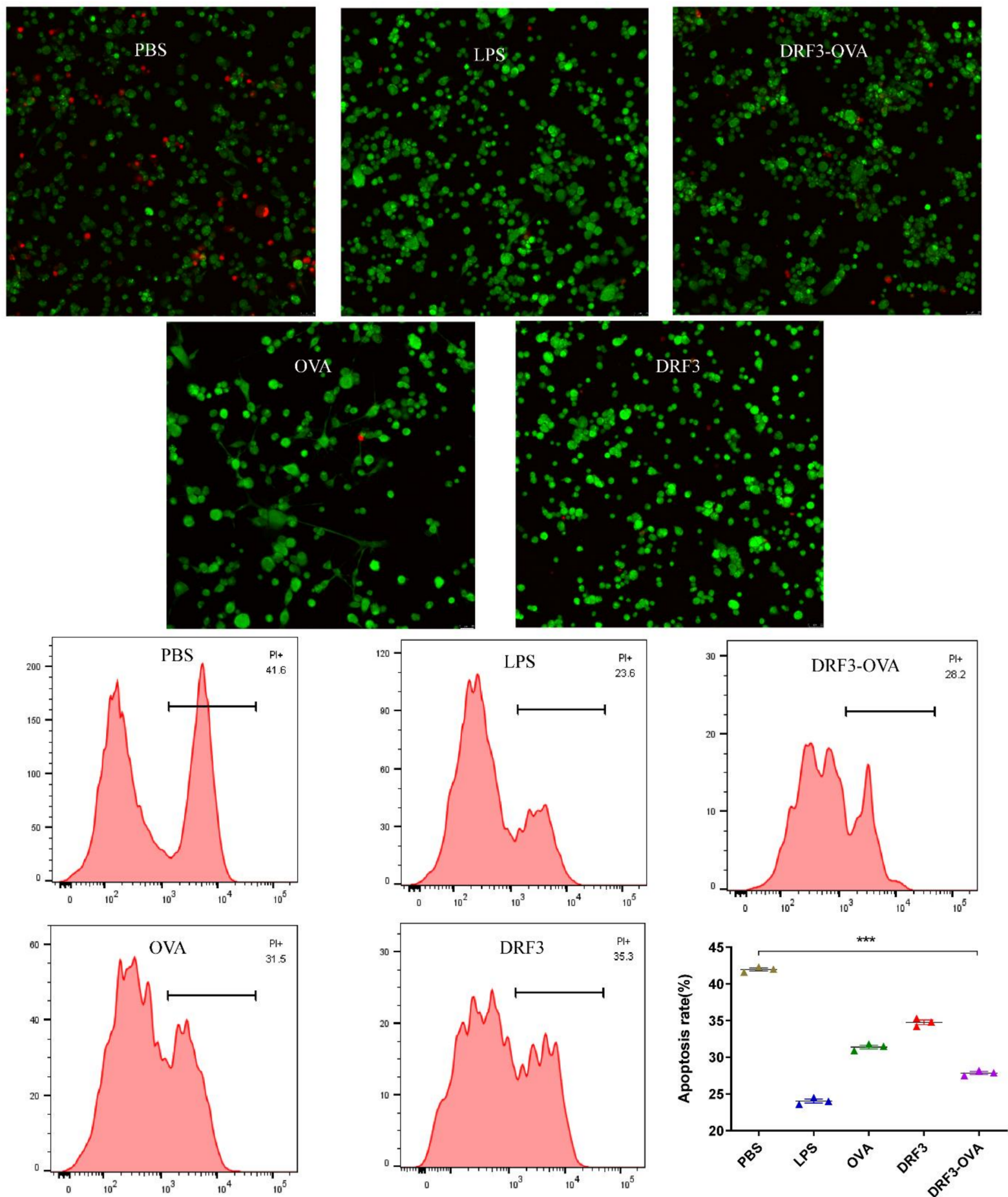

Figure 10. Biocompatibility detection of DRF3. (A) all groups were observed by confocal microscope after co-culture with DC; (B) the apoptosis rate of DC in each group was measured by flow cytometry (The results were repeated three times, shown as mean $\pm \mathrm{SEM}{ }^{* * *}$ means significant differences $p<0.001)$.

Flow cytometry was used to analyze whether the self-assembling peptide DRLF3 is toxic to DC. The apoptosis rate of DC in the PBS group was $41.6 \%, 23.6 \%$ in the LPS group, $31.5 \%$ in the OVA group, $35.3 \%$ in the DRF3 group, and $28.2 \%$ in the DRF3-OVA group (Figure 10B). Compared with the PBS group, the survival rate of DC in the LPS group is increased by 1.76 times, 1.32 times in the OVA group, and 1.48 times in the DRF3-OVA group. As shown in Figure 10B, the apoptosis rate of DC in LPS, OVA, DRF3, and DRF3- 
OVA groups is lower than that in the PBS group. Besides, the apoptosis rate of DC in the DRF3-OVA group is significantly lower than that in OVA and DRF3 group alone, indicating that DRF3 does not affect the survival rate of DC, and significantly improves the survival rate of DC when loading OVA.

\subsubsection{DRF3-FITC Recruits DCs In Vitro}

Our experimental results show that OVA-FITC, DRF3-FITC, and DRF3-OVA-FITC all stimulated immature DCs to form mature DCs. The aggregation of DCs in the OVA-FITC stimulated group was less and had no significant effect on the antigen presentation ability of DCs. DCs in the DRF3-FITC and DRF3-OVA-FITC stimulation groups showed large sheet aggregation, which preliminarily indicated that DRF3-FITC and DRF3-OVA-FITC could collect more DCs in vitro and enhance the antigen presentation ability of DCs compared with OVA-FITC (Figure 11).

OVA

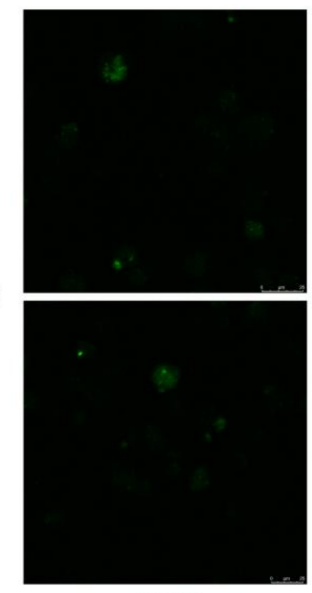

DRF3



(B)

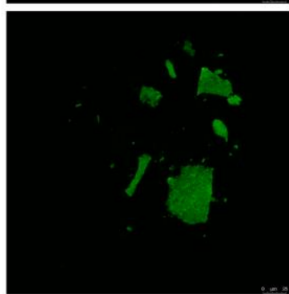

DAPI(DCs)


DAPI(DCs)
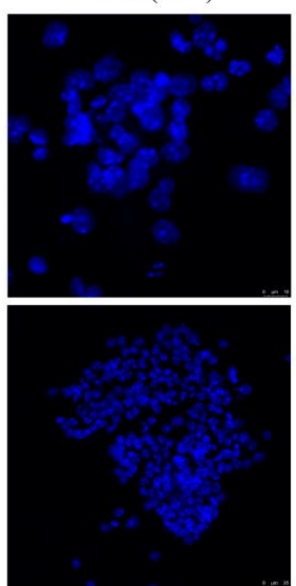

Merge
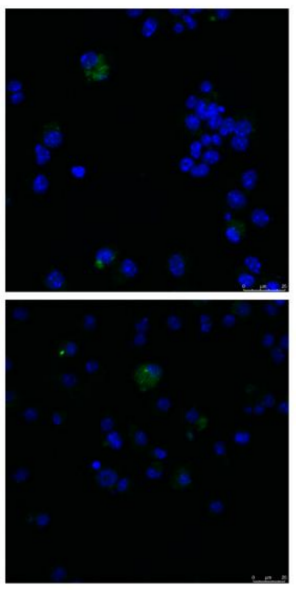

Merge
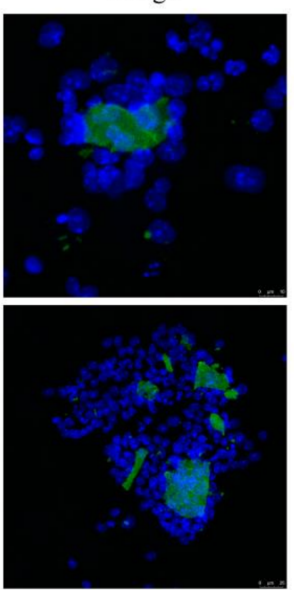

Figure 11. Cont. 
DRF3-OVA

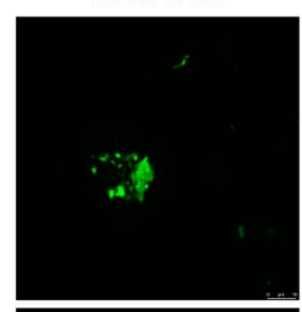

(C)

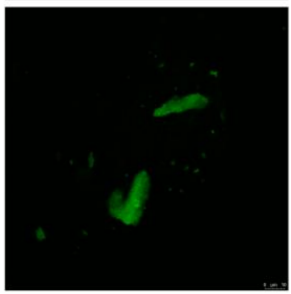

DAPI(DCs)
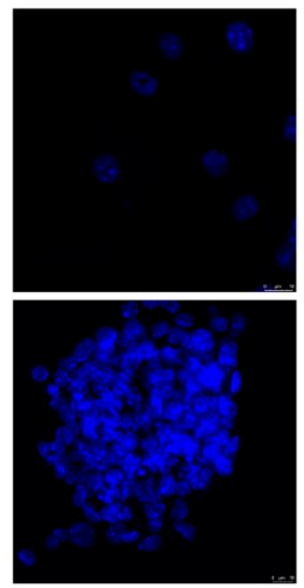

Merge
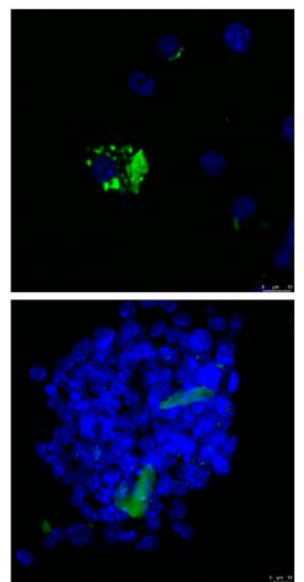

Figure 11. The effect on DCs recruitment. (A) DCs showed an aggregation growth state after OVA stimulation; (B) After stimulation with DRF3, DCs showed a state of largely aggregation growth, indicating that DRF3 can recruit DCs; (C) After being stimulated by DRF3-ova, DCs showed a large aggregation growth state, indicating that DRF3-ova can also recruit DCs, and the effect is better than DRF3 alone.

\subsubsection{Effect on DCs Maturation}

Flow cytometry results show that the percentage of CD86 was $2.85 \%$ in the PBS group, $37.1 \%$ in the LPS group, $23.4 \%$ in the OVA group, $22.8 \%$ in the DRF3 group, and $56.9 \%$ in the DRF3-OVA group (Figure 12). Compared with the PBS group, other groups significantly increased the percentage of CD86. Meanwhile, the percentage of CD86 in the DRF3-OVA group was more than twice that in the OVA and DRF3 groups alone.



DRF3



LPS

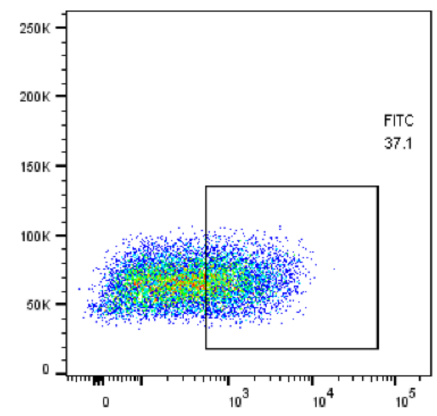

DRF3-OVA

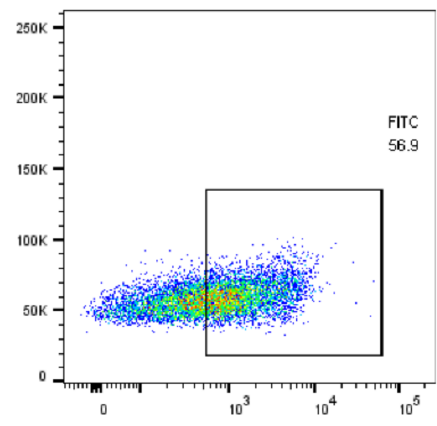

OVA
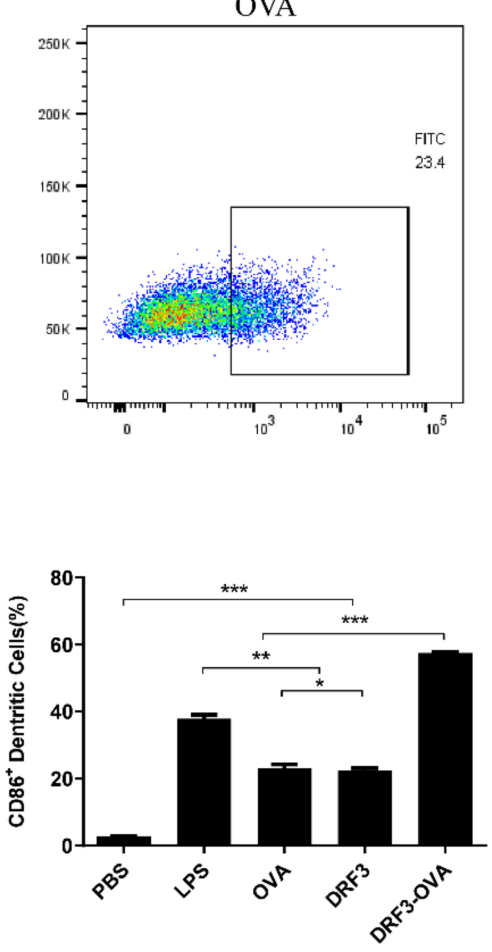

Figure 12. The expression rate of CD86 was detected by flow cytometry (the results were repeated three times, shown as mean $\pm \mathrm{SEM} ;{ }^{*}$ means significant differences $p<0.05 ;{ }^{* *}$ means significant differences $p<0.01{ }^{* * *}$ means significant differences $p<0.001$ ). 


\subsection{Antitumor Properties in Vitro}

The absorbance detection of 786-0 cells stimulated by DRF3 for $24 \mathrm{~h}$ show that the absorbance of DRF3 is 0.376 at $0 \mu \mathrm{g} / \mathrm{mL}, 0.273$ at $1000 \mu \mathrm{g} / \mathrm{mL}, 0.205$ at $2500 \mu \mathrm{g} / \mathrm{mL}$, and 0.119 at $5000 \mu \mathrm{g} / \mathrm{mL}$. The results reveal that the tumor inhibition rate of DRF3 at $24 \mathrm{~h}$ is $27.4 \%$ at $1000 \mu \mathrm{g} / \mathrm{mL}, 45.5 \%$ at $2500 \mu \mathrm{g} / \mathrm{mL}$ and $68.4 \%$ at $5000 \mu \mathrm{g} / \mathrm{mL}$.

The absorbance detection of 786- 0 cells stimulated by DRF3 for $48 \mathrm{~h}$ show that the absorbance of DRF3 is 3.78 at $0 \mu \mathrm{g} / \mathrm{mL}, 3.32$ at $1000 \mu \mathrm{g} / \mathrm{mL}, 2.97$ at $2500 \mu \mathrm{g} / \mathrm{mL}$, and 1.03 at $5000 \mu \mathrm{g} / \mathrm{mL}$. The results demonstrate that the tumor inhibition rate of DRF3 at $24 \mathrm{~h}$ is $12.2 \%$ at $1000 \mu \mathrm{g} / \mathrm{mL}, 21.4 \%$ at $2500 \mu \mathrm{g} / \mathrm{mL}$ and $72.8 \%$ at $5000 \mu \mathrm{g} / \mathrm{mL}$.

The above results indicate that DRF3 has the highest tumor inhibition efficiency when the concentration is $5000 \mu \mathrm{g} / \mathrm{mL}$ (Figure 13).



Figure 13. The toxicity of DRF3 on MCF-7 cells at different concentrations (the results were repeated three times, shown as mean $\pm \mathrm{SEM} ;{ }^{*}$ means significant differences $p<0.05 ;{ }^{* *}$ means significant differences $p<0.01 ;{ }^{* * *}$ means significant differences $\left.p<0.001\right)$.

\section{Discussion}

\subsection{Design of DRF3}

Self-assembling peptide hydrogel is a biomaterial formed by using the "bottomup" principle and existing molecular components in nature through the interaction between molecules [24,25]. Peptide molecules can spontaneously assemble into highly stable and ordered nanostructures through the interaction of non-covalent forces (hydrogen bonding [26,27], electrostatic interaction [28,29], hydrophobic interaction [30,31], van der Waals force and $\pi-\pi$ stacking [32], etc.). DRF3 has a unique amino acid sequence (Ac-(Arg Leu Asp Ile Lys Val Glu Phe) ${ }_{2}-\mathrm{CONH}_{2}$ ), it is composed of hydrophilic amino acids and hydrophobic amino acids 1:1 alternately, among which hydrophilic amino acids are composed of alkaline amino acids and acidic amino acids 1:1 alternately to form neutral polypeptides. Besides, DRF3 uses two N-terminal arginines, leucine, and two C-terminal aspartic acid and glutamic acid, and aminated the C-terminal at the end of the peptide to increase the diversity of peptide interlinking. Furthermore, DRF3 repeats two RLDIKVEF structures, effectively increasing the length of the peptide chain and the stability of the structure, as shown in Figure 14. According to our calculation, there are a total of 24 permutations and combinations of connections. Therefore, DRF3 can be assembled instantly to form a hydrogel structure with a stable structure under the condition of neutral and normal temperature salt solution. This simple and stable assembly method lays a solid foundation for subsequent experiments, solves scientific problems such as a short peptide, long assembly time, and unstable structure (Figure 1), and also shows the potential value of DRF3 in the biomedical field. 




(A)

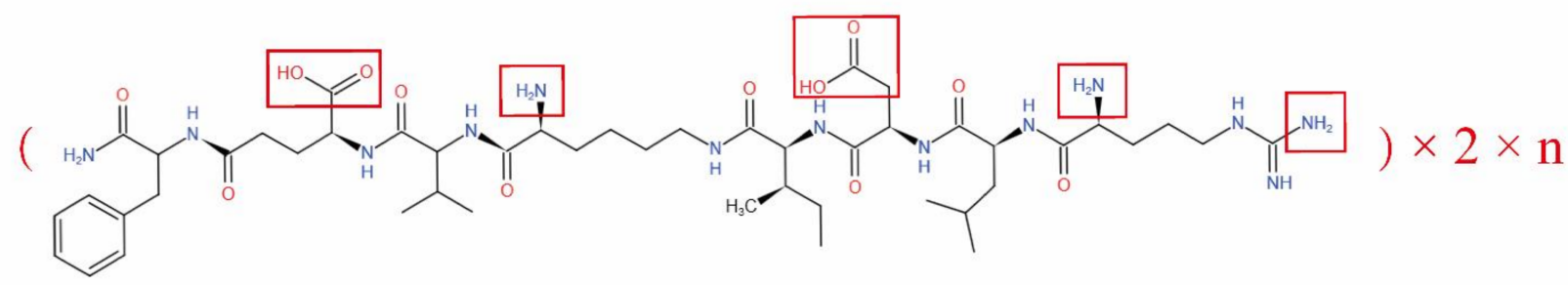



antigens, drugs, vaccines, etc.

(1)
(D)

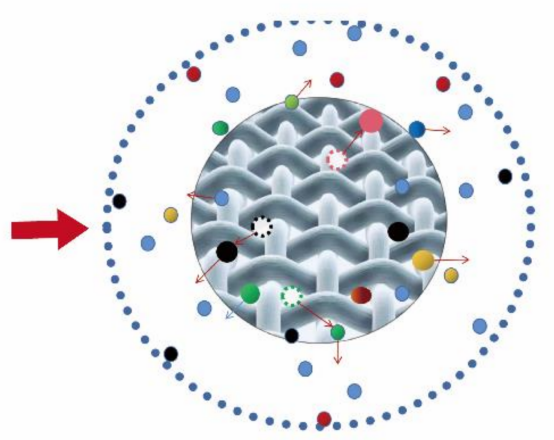

Figure 14. Structure diagram and reasonable model diagram of DRF3. (A) Structure diagram of DRF3; (B) Three-dimensional nanoscaffold structure model of self-assembled peptide hydrogel DRF3; (C) Peptide hydrogel DRF3 is loaded with antigens, drugs or vaccines; (D) Peptide hydrogel DRF3 controlled release antigens, drugs or vaccines, while recruiting immune cells.

\subsection{Characterization of DRF3}

Secondary protein units are generally considered to be stable, such as $\alpha$-helix and $\beta$-sheet [33]. In the ultraviolet region of circular dichroism $(190-240 \mathrm{~nm})$, the main chromophore is the peptide chain [34]. The CD spectrum in this wavelength range contains information about the conformation of the main chain of biological macromolecules [35,36]. DRF3 has a strong positive peak at $190 \mathrm{~nm}$, confirming that it contains an $\alpha$-helix secondary structure. Meanwhile, DRF3 has a negative peak at $211 \mathrm{~nm}$, indicating that it also contains $\beta$-sheet secondary structure (Figure 3 ). Infrared spectroscopy is one of the important methods to analyze the secondary structure of proteins. DRF3 has a strong absorption peak in the range of $1640-1600 \mathrm{~cm}^{-1}$ of the amide I band, revealing that DRF3 contains a $\beta$-sheet secondary structure. Besides, DRF3 has a faint absorption peak in the range of $1661-1646 \mathrm{~cm}^{-1}$ of the amide I band, demonstrating that DRF3 contains $\alpha$-helix secondary structure (Figure 4). Accordingly, DRF3 contains both $\alpha$-helix and $\beta$-sheet structures, and the content of $\beta$-sheet is more than that of $\alpha$-helix. Hydrogels containing these two structures can form ordered nanofiber scaffolds through the variation of nanofibers [37]. Hydrogels are stable in vivo and vitro due to strong intramolecular forces that drive $\beta$-sheet self-assembly [38,39], which laid a foundation for subsequent related experiments of DRF3. 
AFM images show that peptide hydrogel DRF3 has various sizes and forms. The nanofibers are about $\mathrm{nm}$ in diameter (Figure 6), which matched the TEM observation (Figure 7). The higher the hydrophobic content of peptide is, the easier it is to form the scaffold and the better its mechanical properties are [40].

Cryo-SEM images show that peptide hydrogel DRF3 can form nanotubule-like and vesicular structures in PBS (Figure 5). These structures alternate to form an ordered threedimensional nanostructure that can be used for cell culture [41,42] and drug delivery [43].

\subsection{Controlled Release}

The results show that at the 12th hour, the three concentrations of DRF3 complete the controlled release of proteins. The controlled release rate of DRF3 to OVA reached 97\% at $2.5 \mathrm{mg} / \mathrm{mL}, 82 \%$ at $5 \mathrm{mg} / \mathrm{mL}$, and $88.6 \%$ at $2.5 \mathrm{mg} / \mathrm{mL}$ (Figure 9 ), indicating that DRF3 with different concentrations can complete the controlled release of representative antigens and ensure the sustainable effect of antigens.

\subsection{Biocompatibility}

The research demonstrates that DRF3 has good biocompatibility and was even more effective when used in combination with OVA (Figure 10). Besides, DCs in the DRF3-FITC and DRF3-OVA-FITC stimulation groups show large sheet aggregation, which preliminarily indicate that DRF3-FITC and DRF3-OVA-FITC could collect more DCs in vitro and enhance the antigen presentation ability of DCs compared with OVA-FITC (Figure 11). Furthermore, DRF3 can promote DC maturation with an increase in the positive expression rate of CD86 (Figure 12). On account of their bioadhesion, biocompatibility, and biodegradation, hydrogels have been widely used in cell culture, tissue engineering, and local delivery of various drugs/genes [44].

\subsection{Antitumor Properties of DRF3}

Ordinary hydrogels have good biocompatibility, but rarely have immunogenicity and antitumor properties $[45,46]$. In contrast, DRF3 has good biocompatibility and excellent antitumor properties. DRF3 has the highest tumor inhibition efficiency when the concentration is $5000 \mu \mathrm{g} / \mathrm{mL}$, showing a certain degree of concentration dependence (Figure 13).

\section{Conclusions}

Peptide DRF3 with sequence Ac-(Arg Leu Asp Ile Lys Val Glu Phe) $)_{2}-\mathrm{CONH}_{2}$ was successfully synthesized, and its molecular weight and purity reached the expected standard. DRF3 is named according to its sequence. ' $\mathrm{D}$ ' means 'double'. ' $R F^{\prime}$ is the beginning and end of the sequence of DRF3; ' 3 ' is named because DRF3 is the third peptide we synthesized. It repeats two RLDIKVEF structures, effectively increasing the length of the peptide chain and the stability of the structure. DRF3 self-assembles immediately into a colorless transparent gel and forms an ordered nanofiber structure in PBS. DRF3 has many advantages including the ability of stable, slow, and continuous controlled release antigens, good biocompatibility, recruitment of immune cells, promotion of immune cell maturation, and good antitumor ability. This research suggests that DRF3, a self-assembling peptide hydrogel, has great potential in biomedical applications and may pave the way for important medical breakthroughs.

Author Contributions: Conceptualization, R.L.; Data curation, R.L. and G.L.; Formal analysis, R.L.; Funding acquisition, Z.L. (Zhongli Luo); Investigation, R.L.; Methodology, R.L., X.L. and D.S.; Project administration, R.L. and Z.L. (Zhaoxu Li); Resources, R.L.; Software, R.L. and Y.W.; Supervision, R.L. and J.C.; Validation, R.L. and N.L.; Visualization, R.L.; Writing—original draft, R.L.; Writing—review \& editing, R.L. All authors have read and agreed to the published version of the manuscript.

Funding: This program is support by Chengdu Sciobio Surgery Institute, China (Project Number: CSSI-JZ20211021-0002), Zhongli Luo was supported by the grant from the National Natural Science Foundation of China (Project Number: NSFC 31771101). 
Institutional Review Board Statement: Not applicable.

Informed Consent Statement: Not applicable.

Data Availability Statement: The data presented in this study are available in the article.

Acknowledgments: The authors gratefully acknowledge Chengdu Sciobio Surgery Institute, China for the financial support.

Conflicts of Interest: The authors declare no conflict of interest.

Sample Availability: Not applicable.

\section{References}

1. $\quad$ Barani, M.; Sargazi, S.; Mohammadzadeh, V.; Rahdar, A.; Pandey, S.; Jha, N.K.; Gupta, P.K.; Thakur, V.K. Theranostic Advances of Bionanomaterials against Gestational Diabetes Mellitus: A Preliminary Review. J. Funct. Biomater. 2021, 12, 54. [CrossRef]

2. $\mathrm{Hu}, \mathrm{Q} . ; \mathrm{Yu}, \mathrm{X}$.; Gong, S.; Chen, X. Nanomaterial catalysts for organic photoredox catalysis-mechanistic perspective. Nanoscale 2021, 13, 18044-18053. [CrossRef]

3. $\mathrm{Hu}$, J.; Wang, J.; Zhu, X.; Tu, R.S.; Nanda, V.; Xu, F. Design Strategies to Tune the Structural and Mechanical Properties of Synthetic Collagen Hydrogels. Biomacromolecules 2021, 22, 3440-3450. [CrossRef]

4. Ren, Y.; Zhang, Y.; Zhang, H.; Wang, Y.; Liu, L.; Zhang, Q. A Gelatin-Hyaluronic Acid Double Cross-Linked Hydrogel for Regulating the Growth and Dual Dimensional Cartilage Differentiation of Bone Marrow Mesenchymal Stem Cells. J. Biomed. Nanotechnol. 2021, 17, 1044-1057. [CrossRef]

5. Wang, X.; Wang, Q. Enzyme-Laden Bioactive Hydrogel for Biocatalytic Monitoring and Regulation. Acc. Chem. Res. 2021, 54, 1274-1287. [CrossRef]

6. $\quad$ Li, D.; Fei, X.; Wang, K.; Xu, L.; Wang, Y.; Tian, J.; Li, Y. A novel self-healing triple physical cross-linked hydrogel for antibacterial dressing. J. Mater. Chem. B 2021, 9, 6844-6855. [CrossRef]

7. Yu, R.; Petit, E.; Barboiu, M.; Li, S.; Sun, W.; Chen, C. Biobased dynamic hydrogels by reversible imine bonding for controlled release of thymopentin. Mater. Sci. Eng. C 2021, 127, 112210. [CrossRef] [PubMed]

8. Xu, J.; Khan, H.; Yang, L. Hydrogel Paper-Based Analytical Devices: Separation-Free In Situ Assay of Small-Molecule Targets in Whole Blood. Anal. Chem. 2021, 93, 14755-14763. [CrossRef] [PubMed]

9. Kort-Mascort, J.; Bao, G.; Elkashty, O.; Flores-Torres, S.; Munguia-Lopez, J.G.; Jiang, T.; Ehrlicher, A.J.; Mongeau, L.; Tran, S.D.; Kinsella, J.M. Decellularized Extracellular Matrix Composite Hydrogel Bioinks for the Development of 3D Bioprinted Head and Neck in Vitro Tumor Models. ACS Biomater. Sci. Eng. 2021, 7, 5288-5300. [CrossRef] [PubMed]

10. Singh, V.; Kesharwani, P. Recent advances in microneedles-based drug delivery device in the diagnosis and treatment of cancer. $J$. Control. Release 2021, 338, 394-409. [CrossRef]

11. Gaihre, B.; Liu, X.; Li, L.; Lee Miller, A., II; Camilleri, E.T.; Li, Y.; Waletzki, B.; Lu, L. Bifunctional hydrogel for potential vascularized bone tissue regeneration. Mater. Sci. Eng. C 2021, 124, 112075. [CrossRef]

12. Beatty, M.A.; Pye, A.T.; Shaurya, A.; Kim, B.; Selinger, A.J.; Hof, F. Using reversible non-covalent and covalent bonds to create assemblies and equilibrating molecular networks that survive 5 molar urea. Org. Biomol. Chem. 2019, 17, 2081-2086. [CrossRef] [PubMed]

13. Yang, S.; Yan, Y.; Huang, J.; Petukhov, A.V.; Kroon-Batenburg, L.M.J.; Drechsler, M.; Zhou, C.; Tu, M.; Granick, S.; Jiang, L. Giant capsids from lattice self-assembly of cyclodextrin complexes. Nat. Commun. 2017, 8, 15856. [CrossRef]

14. Zhang, R.; Deng, L.; Guo, J.; Yang, H.; Zhang, L.; Cao, X.; Yu, A.; Duan, B. Solvent Mediating the in Situ Self-Assembly of Polysaccharides for 3D Printing Biomimetic Tissue Scaffolds. ACS Nano 2021, 15, 17790-17803. [CrossRef]

15. Zhang, S.; Asghar, S.; Zhu, C.; Ye, J.; Lin, L.; Xu, L.; Hu, Z.; Chen, Z.; Shao, F.; Xiao, Y. Multifunctional nanorods based on self-assembly of biomimetic apolipoprotein E peptide for the treatment of Alzheimer's disease. J. Control. Release 2021, 335, 637-649. [CrossRef] [PubMed]

16. Liu, J.; Wu, C.; Dai, G.; Feng, F.; Chi, Y.; Xu, K.; Zhong, W. Molecular self-assembly of a tyroservatide-derived octapeptide and hydroxycamptothecin for enhanced therapeutic efficacy. Nanoscale 2021, 13, 5094-5102. [CrossRef]

17. Cheng, B.; Yan, Y.; Qi, J.; Deng, L.; Shao, Z.-W.; Zhang, K.-Q.; Li, B.; Sun, Z.; Li, X. Cooperative Assembly of a Peptide Gelator and Silk Fibroin Afford an Injectable Hydrogel for Tissue Engineering. ACS Appl. Mater. Interfaces 2018, 10, 12474-12484. [CrossRef] [PubMed]

18. Atanase, L.I. Micellar Drug Delivery Systems Based on Natural Biopolymers (Basel). Polymers 2021, 13, 477. [CrossRef]

19. Cham, T.-C.; Ibtisham, F.; Fayaz, M.; Honaramooz, A. Generation of a Highly Biomimetic Organoid, Including Vasculature, Resembling the Native Immature Testis Tissue. Cells 2021, 10, 1696. [CrossRef] [PubMed]

20. Miki, T.; Nakai, T.; Hashimoto, M.; Kajiwara, K.; Tsutsumi, H.; Mihara, H. Intracellular artificial supramolecules based on de novo designed Y15 peptides. Nat. Commun. 2021, 12, 3412. [CrossRef]

21. Guo, R.-C.; Zhang, X.-H.; Fan, P.-S.; Song, B.-L.; Li, Z.-X.; Duan, Z.-Y.; Qiao, Z.-Y.; Wang, H. In Vivo Self-Assembly Induced Cell Membrane Phase Separation for Improved Peptide Drug Internalization. Angew. Chem. Int. Ed. 2021, 60, 25128-25134. [CrossRef] 
22. Li, X.; Zhang, H.; Liu, L.; Cao, C.; Wei, P.; Yi, X.; Zhou, Y.; Lv, Q.; Zhou, D.; Yi, T. De novo design of self-assembly hydrogels based on Fmoc-diphenylalanine providing drug release. J. Mater. Chem. B 2021, 9, 8686-8693. [CrossRef] [PubMed]

23. Kim, J.; Narayana, A.; Patel, S.; Sahay, G. Advances in intracellular delivery through supramolecular self-assembly of oligonucleotides and peptides. Theranostics 2019, 9, 3191-3212. [CrossRef] [PubMed]

24. Alzanbaki, H.; Moretti, M.; Hauser, C.A.E. Engineered Microgels-Their Manufacturing and Biomedical Applications. Micromachines 2021, 12, 45. [CrossRef]

25. Sharma, P.; Kaur, H.; Roy, S. Inducing Differential Self-Assembling Behavior in Ultrashort Peptide Hydrogelators Using Simple Metal Salts. Biomacromolecules 2019, 20, 2610-2624. [CrossRef]

26. Gan, Z.; Xu, H. Photoluminescence of Diphenylalanine Peptide Nano/Microstructures: From Mechanisms to Applications. Macromol. Rapid Commun. 2017, 38, 1700370. [CrossRef]

27. Pellach, M.; Mondal, S.; Harlos, K.; Mance, D.; Baldus, M.; Gazit, E.; Shimon, L.J.W. A Two-Tailed Phosphopeptide Crystallizes to Form a Lamellar Structure. Angew. Chem. Int. Ed. 2017, 56, 3252-3255. [CrossRef]

28. Wakabayashi, R.; Higuchi, A.; Obayashi, H.; Goto, M.; Kamiya, N. pH-Responsive Self-Assembly of Designer Aromatic Peptide Amphiphiles and Enzymatic Post-Modification of Assembled Structures. Int. J. Mol. Sci. 2021, 22, 3459. [CrossRef]

29. Yang, C.; Shi, Z.; Feng, C.; Li, R.; Luo, S.; Li, X.; Ruan, L. An Adjustable pH-Responsive Drug Delivery System Based on Self-Assembly Polypeptide-Modified Mesoporous Silica. Macromol. Biosci. 2020, 20, e2000034. [CrossRef] [PubMed]

30. Wang, J.; Qian, Y.; Xu, L.; Shao, Y.; Zhang, H.; Shi, F.; Chen, J.; Cui, S.; Chen, X.; Zhu, D.; et al. Hyaluronic acid-shelled, peptide drug conjugate-cored nanomedicine for the treatment of hepatocellular carcinoma. Mater. Sci. Eng. C 2020, 117, 111261. [CrossRef]

31. Calvelo, M.; Granja, J.R.; Garcia-Fandino, R. Competitive double-switched self-assembled cyclic peptide nanotubes: A dual internal and external control. Phys. Chem. Chem. Phys. 2019, 21, 20750-20756. [CrossRef] [PubMed]

32. Sun, J.; Jiang, X.; Lund, R.; Downing, K.H.; Balsara, N.P.; Zuckermann, R.N. Self-assembly of crystalline nanotubes from monodisperse amphiphilic diblock copolypeptoid tiles. Proc. Natl. Acad. Sci. USA 2016, 113, 3954-3959. [CrossRef] [PubMed]

33. Hamley, I.W.; Brown, G.D.; Castelletto, V.; Cheng, G.; Venanzi, M.; Caruso, M.; Placidi, E.; Aleman, C.; Revilla-López, G.; Zanuy, D. Self-Assembly of a Designed Amyloid Peptide Containing the Functional Thienylalanine Unit. J. Phys. Chem. B 2010, 114, 10674-10683. [CrossRef]

34. De Zotti, M.; Bobone, S.; Bortolotti, A.; Longo, E.; Biondi, B.; Peggion, C.; Formaggio, F.; Toniolo, C.; Bona, A.D.; Kaptein, B.; et al. 4-Cyano- $\alpha$-methyl-1-phenylalanine as a Spectroscopic Marker for the Investigation of Peptaibiotic-Membrane Interactions. Chem. Biodivers. 2015, 12, 513-527. [CrossRef]

35. Xia, Z.; Villarreal, E.; Wang, H.; Lau, B.L.T. Nanoscale surface curvature modulates nanoparticle-protein interactions. Colloids Surf. B Biointerfaces 2020, 190, 110960. [CrossRef]

36. Kurapkat, G.; Krüger, P.; Wollmer, A.; Fleischhauer, J.; Kramer, B.; Zobel, E.; Koslowski, A.; Botterweck, H.; Woody, R.W. Calculations of the CD spectrum of bovine pancreatic ribonuclease. Biopolymers 1997, 41, 267-287. [CrossRef]

37. Zhang, S. Self-assembling peptides: From a discovery in a yeast protein to diverse uses and beyond. Protein Sci. 2020, 29, 2281-2303. [CrossRef] [PubMed]

38. Brown, N.; Lei, J.; Zhan, C.; Shimon, L.J.W.; Adler-Abramovich, L.; Wei, G.; Gazit, E. Structural Polymorphism in a Self-Assembled Tri-Aromatic Peptide System. ACS Nano 2018, 12, 3253-3262. [CrossRef]

39. Rajbhandary, A.; Nilsson, B.L. Investigating the effects of peptoid substitutions in self-assembly of Fmoc-diphenylalanine derivatives. Biopolymers 2017, 108, e22994. [CrossRef]

40. Caplan, M.R.; Schwartzfarb, E.M.; Zhang, S.; Kamm, R.D.; Lauffenburger, D.A. Control of self-assembling oligopeptide matrix formation through systematic variation of amino acid sequence. Biomaterials 2001, 23, 219-227. [CrossRef]

41. Mañas-Torres, M.C.; Gila-Vilchez, C.; Vazquez-Perez, F.J.; Kuzhir, P.; Momier, D.; Scimeca, J.-C.; Borderie, A.; Goracci, M.; Burel-Vandenbos, F.; Blanco-Elices, C.; et al. Injectable Magnetic-Responsive Short-Peptide Supramolecular Hydrogels: Ex Vivo and In Vivo Evaluation. ACS Appl. Mater. Interfaces 2021, 13, 49692-49704. [CrossRef]

42. Godbe, J.M.; Freeman, R.; Lewis, J.A.; Sasselli, I.R.; Sangji, M.H.; Stupp, S.I. Hydrogen Bonding Stiffens Peptide Amphiphile Supramolecular Filaments by Aza-Glycine Residues. Acta Biomater. 2021, 135, 87-99. [CrossRef] [PubMed]

43. Hiew, S.H.; Wang, J.K.; Koh, K.; Yang, H.; Bacha, A.; Lin, J.; Yip, Y.S.; Vos, M.I.G.; Chen, L.; Sobota, R.M.; et al. Bioinspired short peptide hydrogel for versatile encapsulation and controlled release of growth factor therapeutics. Acta Biomater. 2021, 136, 111-123. [CrossRef] [PubMed]

44. Jin, Y.; Wang, H.; Yi, K.; Lv, S.; Hu, H.; Li, M.; Tao, Y. Applications of Nanobiomaterials in the Therapy and Imaging of Acute Liver Failure. Nano-Micro Lett. 2020, 13, 25. [CrossRef]

45. Han, K.; Bai, Q.; Wu, W.; Sun, N.; Cui, N.; Lu, T. Gelatin-based adhesive hydrogel with self-healing, hemostasis, and electrical conductivity. Int. J. Biol. Macromol. 2021, 183, 2142-2151. [CrossRef] [PubMed]

46. He, H.; Li, D.; Lin, Z.; Peng, L.; Yang, J.; Wu, M.; Cheng, D.; Pan, H.; Ruan, C. Temperature-programmable and enzymatically solidifiable gelatin-based bioinks enable facile extrusion bioprinting. Biofabrication 2020, 12, 045003. [CrossRef] 